\title{
SISI-SISI KEINDAHAN BAHASA AL-QUR'AN
}

\author{
Ali Mursyid \\ Mahasiswa Doktor SPs UIN Syarif Hidayatullah Jakarta \\ ali.mursyid@uinjkt.ac.id
}

\begin{abstract}
Abstrak
Selama ini penelitian dan kajian mengenai bahasa al-Qur'an, masih mengangkat beberapa tema lama. Seperti tentang apakah ada bahasa selain bahasa Arab dalam al-Qur'an. Selain itu juga, kajian biasanya seputar kajian Balaghah dan Uslub al-Qur'an. Artikel ini, merupakan hasil penelitian pendahuluan penulis tentang Keindahan Bahasa al-Qur'an dari berbagai sisinya. Kajian ini menggunakan pendekatan Studi Bahasa al-Qur'an, dengan menganalisa unsur-unsur dasar kebahasaan. Yaitu unsur kata, kalimat, kekuatan deskripsi dan visualisasinya, juga tentang bunyi dan nada yang menyertai pengucapan sebuah bahasa. Kajian ini, berusaha mengeksplorasi berbagai sisi keindahan bahasa al-Qur'an, dari sisi keunikan kata, ketepatan pilihan kata dalam al-Qur'an dan segala hal terkait. Juga tentang rahasia keindahan susunan kalimatnya, efek deskripsinya yang mengena, visaulisainya yang begitu jelas dan bunyi-bunyi, baik bunyi kata, maupun bunyi akhir ayat-ayat al-Qur'an yang luar biasa serasi dan indah.
\end{abstract}

Kata Kunci: Kata; Kalimat; Penggabaran; Bunyi/Nada al-Qur'an 


\section{A. Pendahuluan}

Al-Qur'an adalah samudera tak terkira, laut tak bertepi, cinta tak bersyarat. Kitab suci yang satu ini, indahnya tiada tara, kilau cahayanya memantul dari tiap sudutnya, bagai mutiara. ${ }^{1}$ Dan di antara sisi keindahan itu, kita bisa nikmati dari sisi bahasanya, entah karena bahasa al-Qur'an itu mampu mewakili makna yang dikandungnya, entah karena susunan kata-perkata, kalimat perkalimatnya yang unik indah menyentuh nalar serta jiwa, entah dari bunyi-bunyi kata dan kalimatnya, susunan ayatayatnya yang bersajak indah nan berwibawa, entah dari apa lagi entah. Yang jelas, melalui bahasa Arab, al-Qur'an menyampaikan pesan-pesan ilahiah kepada jin dan manusia.

Bahasa al-Qur'an adalah bahasa yang dikenal dengan keindahannya. Sehingga dengan keindahan bahasanya inilah alQur'an disegani oleh kawan dan ditakuti oleh lawan. Hati orangorang kafir Quraiys, pada zaman Nabi Muhammad Saw., boleh jadi belum beriman pada dakwah Islam yang disampaikan Sang $\mathrm{Nabi}$, tetapi hati mereka tetap tidak memungkiri keindahan bahasa al-Qur'an. Sebagian kaum kafir Quraiys saat itu, yang masih menolak dakwah Nabi, jika mendengar al-Qur'an dilantunkan, mereka sontak terheran-heran, terkagum-kagum, terpesona, tetapi karena hati masih diliputi kekafiran dan belum mendapatkan hidayah dari Allah, mereka tetap mengingkari kebenaran Islam, dan menyatakan al-Qur'an yang indah bahasanya itu, sebagai "sihir" belaka.

Tuduhan sihir ini, di satu sisi memang bernada menjelekkan, tetapi di sisi lain, merupakan pengakuan atas efek apa yang dapat dihasilkan dari al-Qur'an ketika dibacakan, yaitu efek sihir, alias efek yang dapat mempengaruhi pendengarnya. Tidak mungkin bisa mempengaruhi pendengar bila memang tidak memiliki keindahan tertentu. Yaitu, keindahan bahasa dan keindahan bunyi yang terdapat dalam al-Qur'an.

1 Ahsin Sakho Muhammad, Oase al-Qur'an: Penyejuk Kehidupan (Jakarta: Penerbit Qaf, 2017), 14. Lihat juga M. Quraish Shihab, Membumikan al-Qur'an (Bandung: Penerbit Mizan, 1992). 
Atas dasar kedahsyatan keindahan bahasa al-Qur'an inilah, sahabat Umar bin Khaththab, yang semula getol memusuhi Nabi, tiba-tiba berbalik, menjadi pembela utama Nabi. Sulit untuk tidak mengatakannya sebagai mu'jizat, seorang pemuda yang merupakan algojo kaum Quraiys saat itu, yang mula-mula menghunus pedang ke mana-mana hendak memerangi Sang Rasul, tiba-tiba berbalik menjadi pembela utama Rasul, hanya karena terpesona, terkagum-kagum dengan al-Qur'an yang dibacakan kepadanya. Umar bin Khaththab, ketika mendengar alQur'an, ia terpesona, terkesima, terserap dan hanyut terseret serta timbul tenggelam oleh keindahan dan kedalaman bahasa alQur'an.

Itulah yang terjadi pada Umar bin Khaththab, lalu bagaimana dengan kita, apakah kita yang bukan sahabat Nabi, tidak hidup di zaman Nabi, tidak menyaksikan wahyu turun kepada Nabi, tetapi bisa merasakan apa yang sahabat Umar rasakan? Apakah kita bisa juga merasakan keindahan bahasa al-Qur'an? Mungkinkah kita yang hina dan penuh dosa ini, bisa menikmati indahnya al-Qur'an dengan cukup mendengarkannya saja? Pertanyaan-pertanyaan ini kiranya perlu dijawab. Untuk menjawab ini, penulis perlu melakukan pembahasan tentang keindahan bahasa al-Qur'an dari berbagai sisinya.

Karena itu masalah yang akan dibahas penelitian ini, dirumuskan dalam pertanyaan-pertanyaan berikut: (1) Bagaimana sisi-sisi keindahan bahasa al-Qur'an pada ranah"kata"?. (2) Bagaimana sisi-sisi keindahan bahasa al-Qur'an pada ranah "kalimat" dan "susunan (tarkîb/ta'lîf) kalimat"?. (3) Bagaimana keindahan bahasa al-Qur'an pada ranah kekuatan penggambaran dari kalimat-kalimatnya?. (4) Bagaimana keindahan bahasa alQur'an pada ranah bunyi?

Agar tidak mengulangi dan tumpang tindih dengan pembahasan dan kajian sebelumnya, dan untuk melihat posisi penelitian ini di hadapan penelitian-penelitian yang sudah dilakukan, maka di bawah ini, adalah penelitian-penelitian sebelumnya yang sudah dilakukan, terkait dengan tema "Bahasa al-Qur'an"; 
1. Penelitian yang dilakukan Muhammad Maimun, tahun 2010, tentang Kosa Kata Asing dalam al-Qur'an. ${ }^{2}$ Penelitian Maimun ini tentang ada tidaknya bahasa asing yang non-Arab dalam al-Qur'an.

2. Penelitian Syuhbanuddin Qalyubi, pada tahun 2006, tentang Stilistika al-Qur'an (Uslûb al-Qur'ân), dengan tema Stilistika Kisah Ibrahim dalam al-Qur'an. ${ }^{3}$ Penelitian Qalyubi ini tentang stilistika (uslûbnya) al-Qur'an yang terdapat ayat-ayat kisah Nabi Ibrahim as.

3. Penelitian Tika Fitriyah, pada tahun 2015, tentang Stilistika al-Qur'an (Uslûb al-Qur'ân), dengan tema Stilistika Kisah Nabi Luth dalam al-Qur'an. ${ }^{4}$

4. Penelitian Anshori Sayuthi, tentang kemu'jizatan bahasa alQur'an, khususnya mengenai kemu'jizatan bunyi/suara ( $i$ 'jaz shauty), diterbitkan tahun 2012, dengan tema Fonetik dan Fonologi al-Qur'an. ${ }^{5}$

5. Penelitian Anshori Sayuthi, tentang kemu'jizatan bahasa alQur'an, khususnya mengenai kemu'jizatan bunyi/suara ( $i^{\prime} j a z$ shauty), diterbitkan tahun 2011, dengan tema Sifat-Sifat Bunyi al-Qur'an: Sebuah Tinjauan Fonetis.

6. Penelitian Yayan Nurbayan, dosen UPI, dengan tema Analisis Ayat-Ayat Kinâyah dalam al-Qur'an. Jadi ini penelitian dengan pendekatan ilmu Balâghah.

7. Peneltian Suniarti Sunny, tahun 2014, tentang gaya bahasa alQur'an, dengan mengangkat tema Gaya Bahasa dalam Surah Ar-Rahman (Kajian Stilistika). ${ }^{7}$

8. Penelitian Nurhidayat, dosen fakultas Tarbiyah dan Tadris IAIN Bengkulu, dipubliksikan tahun 2016, dengan judul Penggunaan Gaya Bahasa Simile dalam al-Qur'an. ${ }^{8}$

${ }^{2}$ Muhammad Maimun, Kosa Kata Asing dalam al-Qur'an (Tesis Program Pascasarjana UIN Sunan Kalijaga Yogyakarta, 2010).

3 Syuhbanuddin Qalyubi, Stilistika Kisah Ibrahim dalam al-Qur'an (Disertasi UIN Sunan Kalijaga Yogyakarta, 2006).

${ }^{4}$ Tika Fitriyah, Stilistika Kisah Nabi Luth dalam al-Qur'an (Tesis Program Pascasarjana UIN Sunan Kalijaga Yogyakarta, Prodi Studi Agama Islam dan Filsafat, konsentrasi ilmu bahasa Arab, 2015).

5 Ahmad Sayuti Anshari, Fonetik dan Fonologi al-Qur'an, (Jakarta: Penerbit Amzah, 2012)

${ }^{6}$ Ahmad Sayuti Anshari, "Sifat-Sifat Bunyi al-Qur'an: Sebuah Tinjauan Fonetis", dimuat di Misykat, jurnal Pascasarjana IIQ Jakarta, Vol. III, No. 1 Februari, 2010.

7 Suniart Sunny, Gaya Bahasa dalam Surah Ar-Rahman: Kajian Stilistika (Tesis Program Pascasarjana UIN Sunan Kalijaga Yogyakarta, 2014). 
9. Penelitian Moh. Mukhlas, dosen Universitas Darussalam Gontor, dipublikasikan tahun 2014, dengan judul Fenomena Pragmatis dalam al-Qur'an: Kajian Atas Bentuk Imperatif pada Surah an-Nur. ${ }^{9}$

10. Penelitian Istianah, dosen STAIN Kudus, dipublikasikan tahun 2014, dengan judul Stilistika al-Qur'an: Pendekatan Sastra Sebagai Analisis dalam Menginterpretasikan alQur'an. ${ }^{10}$

11. Penelitian Agus Tricahyo, dosen STAIN Ponorogo, dipublikasikan tahun 2014, dengan judul Stilistika al-Qur'an:
Memahami Fenomena Kebahasaan al-Qur'an dalam Penciptaan Manusia. ${ }^{11}$

12. Penelitian Baiq Raudhatussolihah, tahun 2016, dengan tema Analisis Linguistik dalam al-Qur'an (Studi Semantik Terhadap QS. al-'Alaq). ${ }^{12}$

13. Penelitian Wagino Hamid Hamdani dan Maman Abdurrahman, keduanya dosen UPI, tentang bahasa alQur'an, yang dipublikasikann pada tahun 2014, dengan judul Fenomena Polisemik Bahasa Arab dalam al-Qurán dan Implikasi Pembelajarannya. ${ }^{13}$

14. Penelitian Khalida Iwatunnisa, tentang bahasa al-Qur'an, pada tahun 2015, dengan tema Keserasian Bunyi Akhir Ayat dalam QS. al-Insyirah (Kajian Aspek Fonologi al-Qur'an). ${ }^{14}$

${ }^{8}$ Nurhidayat, "Penggunaan Gaya Bahasa Simile dalam al-Qur'an", dalam jurnal Manhaj, diterbitkan Fakultas Tarbiyah dan Tadris IAIN Bengkulu, Vol. 4 No. 2, Mei-Agustus 2016.

${ }^{9}$ Moh. Mukhlas, "Fenomena Pragmatis dalam al-Qur'an: Kajian Atas Bentuk Imperatif pada Surah an-Nur", dalam jurnal At-Ta'dib, Universitas Darussalam Gontor, Vol. 9, No. 1, Juni 2014.

${ }^{10}$ Istianah, "Stilistika al-Qur'an: Pendekatan Sastra Sebagai Analisis dalam Menginterpretasikan al-Qur'an", dalam jurnal Hermeneutika, diterbitkan STAIN Kudus, Vol. 8, No, 2, Desember 2014.

11 Agus Tricahyo, "Stilistika al-Qur'an: Memahami Fenomena Kebahasaan al-Qur'an dalam Penciptaan Manusia", dalam jurnal Dialogia, diterbitkan oleh STAIN Ponorogo, Vol. 12, No. 1, Juni 2014.

12 Baiq Raudhatussolihah, Analisis Linguistikk dalam al-Qur'an: Studi Semantik Terhadap QS. al-'Alaq, Tesis pada Program Pascasarjana UIN Alauddin Makassar, 2016.

13 Wagiono Hamid Hamdani dan Maman Abdurrahman, "Fenomena Polisemik Bahasa Arab dalam al-Qur'an dan Implikasi Pembelajarannya”, dalam jurnal Bahasa dan Sastra, UPI, Vol. 14, No. 1, April 2014.

${ }^{14}$ Khalida Iwatunnisa, Keserasian Bunyi Akhir Ayat dalam QS. alInsyirah: Kajian Aspek Fonologi al-Qur'an, (Skripsi Jurusan Ilmu al-Qur'an dan Tafsir, Fakultas Ushuluddin dan Pemikiran Islam, UIN Sunan Kalijaga Yogyakarta, 2015). 
Demikianlah, dari beberapa peneltian terdahulu, menunjukkan, belum adanya sama sekali penelitian dengan tema yang sama dan dengan rumusan masalah yang sama persis dengan penelitian ini. Penelitian-penelitian terdahulu di atas, juga menunjukkan, bahwa penelitian-penelitian yang sudah dilakukan, bisa digunakan sebagai literatur tambahan, dalam penelitian kali ini.

Berdasarkan datanya, penelitian ini adalah jenis penelitian deskriptif kualitatif, ${ }^{15}$ Penelitin ini juga merupakan penelitian kepustakaan (library research) dan bukan penelitian lapangan. Adapun sumber data primer penelitian ini adalah: (1) Al-Qur'an dan Terjemahannya, dan; (2) Buku-buku tentang Bahasa alQur'an (lughat al-Qur'an). Sementara sumber sekundernya adalah buku-buku, artikel-artikel yang terkait dengan pokok bahasan dalam penelitian ini. Kamus-kamus, juga ensiklopediensiklopedi, buku-buku 'Ulûm al-Qur'ân, buku-buku Tafsir dan lain sebagainya. Data primer dan sekunder terkumpul, dibaca dan dianalisa secara deskriptif. ${ }^{16}$

Dalam melakukan analisa, dalam penelitian ini, peneliti menggunakan pendakatan lingusitik (lughah), yang mencoba menganalisa bahasa al-Qur'an dari unsur yang paling inti, yaitu unsur kata, unsur kalimat dan susunannya, deskripsinya dan bunyi dari kata dan kalimatnya.

${ }^{15}$ Mahsun, Metode Penelitian Bahasa (Jakarta: Rajawali Press, 2005), 256-257.

${ }^{16}$ Sumadi Suryabrata, Metodologi Penelitian, cet. II (Jakarta: Rajawali Press, 1985), 19. Bandingkan dengan Cholid Narbuko dan Abu Achmadi, Metodologi Penelitian, cet.II (Jakarta: Bumi Aksara, 2001), 44. Lihat juga Nyoman Kutha Ratna, Metode Penelitian: Kajian Budaya dan Sosio Humaniora Pada Umumnya, Yogyakarta: Pustaka Pelajar, 2010), 467. 


\section{B. Pembahasan}

Menurut Muhammad Rawwas Qal'ah ji, keindahan suatu bahasa ditentukan oleh hal-hal berikut: (1) Keindahan unsurunsur dasarnya; (2) Keserasian unsur-unsur dasar tersebut, di mana antara satu dengan yang lain tidak ada kerancuan di dalamnya; (3) Keindahan atau ketepatan maknanya agar mencapai maksud yang diungkapkan. ${ }^{17}$

Yang dimaksud dengan unsur-unsur dasar pada poin pertama pada paragraf pertama di atas, adalah kata, kalimat dan penggambaran yang terdapat dalam susunan kalimat. Atas dasar inilah, analisa dalam tulisan ini terhadap bahasa al-Qur'an di fokuskan pada analisa dari beberapa ranah, ranah "kata", ranah "susunan kalimat", ranah "kekuatan penggambaran" dalam kalimat-kalimatnya, serta ranah "bunyi", maka keindahan Bahasa al-Qur'an bisa dijelaskan di bawah ini.

1. Rahasia Keunikan dan Keindahan "Kata" dalam al-Qur'an

Keunikan "kata" dalam al-Qur'an di antaranya adalah ketepatan pilihan kata yang digunakannya. Di antara bukti ketepatan pemilihian kata (diksi) dalam al-Qur'an adalah:

a) Ketepatan pilihan "kata"

Kata-kata dalam al-Qur'an adalah kata-kata dari bahasa Arab, tetapi kata-kata bahasa Arab dalam al-Qur'an adalah kata yang terpilih dan digunakan secara tepat, yaitu tepat maknanya. Sebagai contoh misalnya kata آسن (âsin) pada Q.S. Muhammad, ayat 15 :

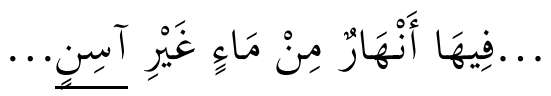

Kata آس pada ayat di atas berarti payau. Ada kata lain yang juga bermakna payau, yaitu kata منت (muntun). Bedanya, kalau âsin berarti air payau yang disebabkan oleh karena lama didiamkan di suatu tempat. Saking lamanya didiamkan di suatu tempat, air jernih bisa berubah sedikit warna dan rasanya menjadi payau, ini disebut $\hat{a} s i n$, air payau karena proses alami. Sementara muntun, berari air payau yang disebabkan karena kejatuhan kotoran, bukan karena lamanya didiamkan dalam satu tempat ${ }^{18}$.

${ }^{17}$ Muhammad Rawwas Qal'ahji, Lughat al-Qur'an Lughat al- 'Arab alMukhtarah, (Dharhan, Dar al-Nafa' is, 2017), 67 .

${ }^{18}$ Muhammad Rawwas Qal'ahji, Lughat al-Qur'an Lughat al- 'Arab alMukhtârah., 68. 
Karena itu âsin adalah air payau yang lebih jernih dari muntun. Kata âsin dipilih untuk ayat di atas, dan bukan kata muntun, adalah pilihan yang sangat tepat. Bukankah ayat di atas, sedang membicarakan bahwa di surga ada sungai-sungai yang airnya tidak payau, karena dipilihh kata âsin, maka air sungai di surga itu, payau yang karena proses alami saja, payau sedikit saja pun tidak. Jadi air sungai-sungai surga sangat jernih, payau sedikit pun tidak.

Al-Qur'an juga menggunakan kata أساطر (asâthir) pada Q.S. al-An'am: 25.

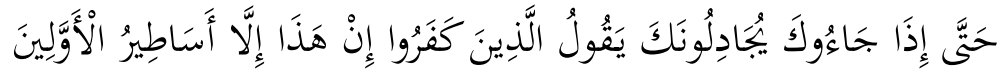

Artinya: "Sehingga apabila mereka datang kepadamu untuk membantahmu orang-orang kafir itu berkata "ini (AlQur'an) tidak lain hanyalah dongengan orang-orang terdahulu."

Pada ayat di atas, digunakan kata أساطر (asâthir), yang berarti cerita atau berita bohong. Ini sebagaimana yang digunakan oleh Kabilah Jurhum. Selain kata asâthir untuk makna cerita atau pembicaraan digunakan kata كلام (kalâm). ${ }^{19}$ Bedanya kata kalâm, tidak mengarah pada arti "pembicaraan atau cerita bohong", tidak seperti asâthir. Jadi pemilihan kata asâthir untuk konteks ayat di atas, di mana orang-orang kafir menuduh al-Qur'an sebagai cerita bohong.

Dalam bahasa Arab, kata زوج (zauj) berarti pasangan, kata زوجان (zaujân) berarti sepasang suami istri. Istilah زوج فلان berarti pasangan bagi seorang laki-laki. Ini hampir sama dengan arti istilah إمرائة فلان yang juga berarti perempuan atau pasangannya seseorang. Jadi dalam bahasa Arab kata زوج (zauj) dan kata إمراءة (imra'ah), hampir sama maknanya. Tetapi dalam al-Qur'an kata zauj dan kata imra'ah ini ternyata digunakan secara berbeda ${ }^{20}$. Kata zauj digunakan untuk pasangan yang serasi, baik dalam hal keimanan maupun serasi dalam hal lainnya, sebagaimana dalam Q.S. al-Baqarah, ayat 102.

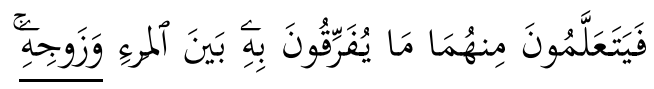

${ }^{19}$ Muhammad Rawwas Qal'ahji, Lughat al-Qur'an Lughat al- 'Arab alMukhtârah., 68.

${ }^{20}$ Muhammad Rawwas Qal'ahji, Lughat al-Qur'ân Lughat al- 'Arab alMukhtârah., 68-69. 
Artinya: Maka mereka mempelajari dari kedua malaikat itu apa yang dengan sihir itu, mereka dapat menceraikan antara seorang (suami) dengan isterinya.

Karenanya, kata zauj yang bentuk pluralnya adalah azwâj digunakan untuk menyebut pasangan atau istri-istri Nabi, yang sama-sama beriman sebagaimana Nabi ang menjadi suaminya. Ini sebagaimana dalam Q.S. al-Ahzab, ayat 59, berikut;

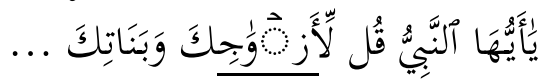

Artinya: Wahai Para Nabi, katakanlah kepada isteriisterimu, anak-anak perempuanmu.

Sementara kata imra'ah digunakan al-Qur'an untuk menyebut pasangan yang tidak seimbang, baik dalam hal keimanan maupun lainnya. Sebagaimana dalam Q.S. at-Tahrîm, ayat 11, disebut istilah إمرأة فرعون (imra'ah fir'aun) untuk menyebut pasangannya atau istrinya Fir'aun yang sudah beriman atau mentauhidkan Allah. Dalam tafsir di antaranya dkenal dengan nama Asia, Asia istri Fir'aun deriman pada Allah, Fir'aunnya ingkar. Pasangan yang tidak serasi, maka kata yang dipilih imra'ah dan bukan zauj. Begitu juga dalam Q.S. at-Tahrîm, ayat 10, istri Nabi Nuh dan Istri Nabi Luth disampaikan dalam istilah إمرأة نوح (imra'ah Nûh ) dan إمرأة لوط (imra'ah Lûth), karena baik istri Nabi Nuh dan istri Nabi Luth, meski mereka istri Nabi, tetapi mereka tidak beriman sebagaimana suaminya.

Ketapatan pilihan kata dalam al-Qur'an, sehingga sangat sesuai dengan konteks pembicaraannua, di antaranya juga bisa dilihat pada firman Allah berikut ini.

$$
\text { وان الله عنده اجر عظيم }
$$

Artinya "Dan sesungguhnya di sisi Allah ada pahala yang besar”. (Q. S. al-Anfal:28).

Pada ayat di atas, al-Qur'an menggunakan kata العظيم dan tidak menggunakan kata الكيير. Karena العظيم (besar dan agung) lawan kata الحقير (kecil dan hina) sedang lawan kata الصغير (kecil). Jadi penggunaan kata العظيم pada ayat di atas, lebih tepat dan lebih baik dari pada menggunakan kata الكبير الكغير.

21 Ahmad Mukhtar 'Umar, Lughat al-Qur'an, Dirasah Tautsiqiyah Fanniyah (Kuwait: Muassasah al-Kuwait li Taqaddum al-'Ilmi, 1997), 145. 
b) Tidak ada Kata yang Janggal

Di antara keunikan kata di dalam al-Qur'an adalah tidak ada kata yang janggal yang ditolak atau kata-katanya kotor dan tidak layak serta tidak disukai. Sehingga kata-kata dalam alQur'an lebih mudah dipahami akal, dirasakan oleh hati dan kandungannya bisa dirasakan jiwa. Menurut imam 'Abd al-Qâhir al-Jurjâni, jika kita membaca salah satu surat yang panjang dalam al-Qur'an, maka kamu tidak akan menemukan kata pun yang janggal. Para ulama membahas bahwa dalam al-Quran, terdapat kata yang janggal tetapi hanya sedikit, dan itu pun kata-katanya berupa kiasan. Ini sebagaimana dalam firman Allah Swt berikut:

$$
\text { واشربو في قلوبهم العجل بكفرهم }
$$

Artinya: Dan telah diresapkan ke dalam hati mereka itu (kecintaan menyembah) anak sapi karena kekafirannya.

Pada ayat di atas kata yang dianggap sebagai kata yang janggal adalah kata واشربوا yang artinya di minumkan. Tapi pada ayat di atas, makna yang dipakai adalah makna kiasannya, yaitu diminumkan, dikiaskan menjadi diserapkan. Ketika kata dminumkan dipahami dengan makna diserapkan, maka kejanggalan itu tidak ada lagi.

Perhatikan firman Allah Swt di bawah ini:

تلك اذاقسمة ضيزى

Artinya: "yang demikian itu tentulah suatu pembagian yang tidak adil”. (Q.S an-Najm:22).

Dalam ayat di atas kata ضيزى mempunyai makna zhalim. Tidak memakai kata ظالما kerena yang dikehendaki ayat di atas justru zhalim yang sangat zhalim. Kata dhîzâ ini termasuk kata yang janggal. Tetapi kejanggalan itu ditempatkan di tempat yang sesuai, keseusuaian ini bila dilihat pada konteks ayat-ayat sebelumnya. Ayat di atas adalah bagian dan surah an-Najm yang akhir ayat-ayatnya memakai alif maqshûrah. Selain itu, pada ayat di atas, di mana pada ayat-ayat sebelumnya, orang-orang kafir Quraisy, meenganggap berhala-berhala itu anak perempuan Allah, lalu Allah mengatakan kalau begitu, a lakum al-dzakaru wa lahu al-untsa (apakah berarti kalian wahai kafir Quraiys punya anak laki-laki, dan Allah punya anak perempuan). 
Padahal punya anak perempuan, di masa Jahiliyah itu, dianggap hina, sementara punya anak laki-laki dianggap mulia, bukankah kalau menganggap Allah punya anak perempuan (yang berupa berhala itu), sementara orang orang kafir Quraisy, punya anak laki-laki, bukankah itu pembagian yang zhalim dan kurang ajar, makanya kemudian dikatakan pada ayat di atas tilka idzâ qismatun dhâzâ. ${ }^{22}$

\section{c) Struktur Kata}

Selain pada ketepatan pilihan kata dan maknanya, keunikan dan keindahan kata dalam al-Qur'an, juga terletak pada struktur yang membangun kata-kata itu se3ndiri. Kata terbangun dari huruf-huruf, huruf-huruf yang terangkai menjadi kata. Di antara keunikan kata, adalah justru dari struktur huruf-huruf yang membangun kata. Contoh yang menunjukkan keunikan struktur kata dalam al-Qur'an adalah adanya perbedaan makna pada bentuk Isim Fa'il, seperti kata شاهد (syâhid), yang berarti orang yang menyaksikan, dengan bentuk shighat mubâlaghah, seperti شهيد (syahîd) yang berarti juga orang yang menyaksikan. Perbedaanya, kalau syâhid menunjukkan arti orang yang menjadi saksi tetapi tidak mengetahui betul-betul apa yang disaksikannya. Sedangkan kata شهيد ditujukan untuk orang yang mengetahui betul-betul peristiwa serta faktor terjadinya peristiwa tersebut. Hal ini sebagaimana dalam al-Qur'an Surah al-Baqarah ayat 282:

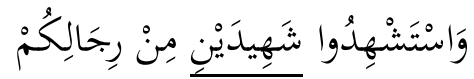

Artinya: "Dan persaksikanlah dengan dua orang saksi laki-laki diantara kamu."

Pada ayat di atas, penggunaan kata شهيد dan bukan شاهد sangat tepat, karena memang dalam persaksian, yang dibutuhkan adalah saksi yang mengerti betul perihal yang disaksikannya ${ }^{23}$. Ini juga membuktikan, bahwa pebedaan huruf yang menjadi struktur kata, mempengaruhi perbedaan makna.

Contoh lainnya adalah kata يضّ (yudharru) memiliki arti diberi bahaya atau dipersulit yang ringan. Tetapi jika bentuknya menggunakan kata يضار (yudhârru) maka artinya diberi bahaya atau dipersulit dengan sangat.

${ }^{22}$ Ar-Râfi'î, I'jâz al-Qur'ân wa al-Balâghah al-Qur'âniyah (Beirut: Dâr al-"Arabiyah, 1973), 230.

${ }^{23}$ Muhammad Rawwas Qal'ahji, Lughat al-Qur'ân Lughat al- 'Arab alMukhtârah., 70. 
Makna ini diambil dari tambahan alif pada bangunan kata yang menunjukkan tambahan makna Dalam al-Qur'an sendiri, menggunakan kata يضار (yudhârru) seperti dalam Q.S. al-Baqarah 282:

$$
\text { وَلَا يُضَارَّ كَاتِبِّ وَلَا شَهِيدٌُ }
$$

Maka maksud dari ayat di atas adalah bahwa dalam soal hutang piutang, penulis atau pencatat hutang, jangan terlalu dipersulit karena apa yang ditulisnya, begitu juga saksi ${ }^{24}$. Dalam Tafsir al-Jalalain, dikatakan dalam soal hutang piutang, baik yang mencatat hutang dan pihak saksi, atau pihak yang hutang dan yang berhutang, jangan terlalu dipersulit dan jangan saling mempersulit. ${ }^{25}$

Selain contoh di atas, di antara yang menunjukkan keseimbangan susunan katanya. Yaitu banyaknya fi'il tsulasi yang terdapat dalam al-Quran. Tidak lebih dari 17 kata rubai, dan jika ada yang khumasi, itu bukan bahasa Arab, tetapi bahasa lain yang di-Arabkan.

Yang perlu diperhatikan mengenai keseimbangan susunan kata dalam al-Qur'an. Kata-kata dalam al-Qur'an, banyak menggunakan kata yang terdiri dari tiga huruf, atau yang biasa disebut tulâtsî. Tidak lebih dari 17 kata ruba'i (yang terdiri 4 huruf), dan jika ada yang khumâsi (terdiri dari 5 huruf), itu yang bukan aslinya bahasa Arab, tetapi bahasa lain yang di-Arabkan. ${ }^{26}$

\section{d) Ada Keserasian $\underline{H}$ arakat}

Keserasian harakat dalam susunan huruf-hurufnya dalam al-Qur'an menjadikan kata tepat dalam pengucapan dan maknanya dan harakatnya mendukung satu sama yang lain. Jika ada harakat yaang berat karena satu sebab tertentu atau mungkin juga susah diucapkan dalam al-Qur'an maka ini sesuatu yang aneh. Jika ada harakat yang aneh dan berat seperti dalam pengucapan harakat-harakat "bin nudzur" pada ayat di bawah ini, maka sebelumnya dipersiapkan sebelumnya, disusun harakatharakat sebelumnya yang juga berat. Jika sebelumnya biasa dengan yang berat, maka ketika kata nudzur diucapkan , jadi tidak terasa beratnya lagi. Ini sebagaimana dalam ayat di bawah ini:

${ }^{24}$ Muhammad Rawwas Qal'ahji, Lughat al-Qur'ân Lughat al- 'Arab alMukhtârah., 69.

${ }^{25}$ Jalâluddin as-Suyûthi, Jalâkuddîn al-Mahalli, Tafsîr al-Jalâlain.

${ }^{26}$ Ar-Râfi' '̂̀, I'jâzz al-Qur'ân wa., 229. 
Artinya: "Dan sesungguhnya dia (Luth) telah memperingatkan kepada mereka akan azab-azab kami, maka mereka mendustakan ancaman-ancaman itu’.

Perhatikan ayat di atas, mari kita lihat, sebelum kata بالنذر (bi al-nudzur), yang dirasakan berat susunan harakatnya, sebelumnya susunan harakat-harakatnya dalam pengicapannya juga berat. Perhatikan, ada qalqalah pada huruf $s$ (dal) di laqad, dan ada qalqalah pada huruf $b$ (tha) di bathsyatanâ. Perhatikan pada ayat di atas, juga ada harakat fathah yang berturut-turut setelah huruf ش (syin) sampai setelah huruf, ( $\mathrm{ra}$ ), dengan diselingi dua bacaan panjang ( $\mathrm{mad}$ ). Yang demikian adalah merupakan susunan harakat yang terasa berat di pengucapan. Karena itu pada pengucapan harakat pada بالنذر (bi al-nudzur), tidak lagi terasa berat. ${ }^{27}$

\section{e) Bunyi Kata}

Di keserasian harakat dan pengucapannyam, kata dalam al-Qur'an memiliki bunyi yang unik, khas dan indah. Kata-kata dalam al-Qur'an mengandung bunyi. Bunyi pada kata-kata di dalam al-Qur'an mengisyaratkan pada maknanya. Dari bunyinya, sebuah kata kadang bisa diketahui maknanya, tanpa buka kamus. Sebagai contoh, misalnya bunyi suara api, orang Arab umum memakai kata جلبة (jalabah), sementara orang-orang Quraisy menggunakan kata حسيس (hasîs) untuk makna bunyi api. Tetapi sebagian orang Arab dan non-Arab merasa bahwa pengulangan (hasîs) yang termasuk salah satu huruf shafir itu bunyinya menyerupai desisan api. Jadi al-Qur'an memilih kata (hasîs) untuk suara desis api ${ }^{28}$. Sebagaimana dalam Q.S. al-Anbiya' :102.

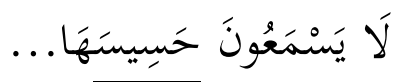
neraka)"

Artinya: "Mereka tidak mendengar bunyi desisnya (api neraka)

\footnotetext{
${ }_{28}^{27}$ Ar-Râfi'î, I'jâz al-Qur'ân wa., 227-228.

28 Muhammad Rawwas Qal'ahji, Lughat al-Qur'ân Lughat al- 'Arab alMukhtârah., 70.
} 
Kata حَسِيس (hasîs) terambil dari kata حسis) yang berarti rasa atau indra. Yang dimaksud di sini adalah suara yang sampai ke indra pendengar. Neraka dilukiskan kobaran apinya begitu keras sehingga dapat terdengar dari kejauhan. Hamba-hamba Allah yang taat dan yang dilukiskan oleh ayat di atas, jangankan melihat kobaran api neraka yang menakutkan, mendengar desisnya pun tidak. Ini mengisyaratkan bahwa memang neraka sangat jauh dari mereka. ${ }^{29}$

Contoh lainnya, sebagaimana dalam Q.S. ai-Takwîr, ayat 17-18, berikut:

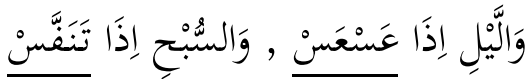

Artinya: "Demi malam apabila telah larut, dan demi subuh apabila fajar telah menyingsing. (Q. S. At-takwir :17-18).

Maka dalam kalimat تنفّ dan maknanya sudah bisa dirasakan tanpa melihat kamus. Bunyi as'as dan bunyi tanaffas, pada dua kata dalam ayat di atas seolah memberi tahu maknanya, dan dengan demikian pendengar seolah bisa tahu atau minimal menyadari maknanya, meski belum tahu persis maknanya. Sehingga pendengar atau pembaca al-Qur'an bisa tahu atau menyadari makna, atau arah makna kata, meski tanpa membuka kamus atau terjemahannya. ${ }^{30}$

Perhatikan firman Allah di bawah ini:

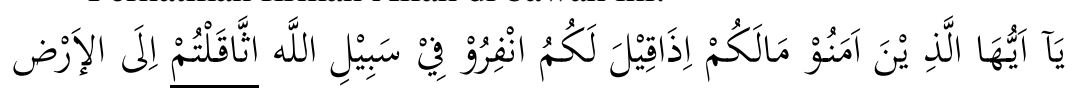

Artinya: "Hai orang-orang yang beriman apakah sebabnya bila dikatakan kepadamu: berangkatlah untuk berperang pada jalan Allah. Kamu merasa berat dan ingin tinggal di tempat?"

Pada ayat di atas, dari kata اثَّلقتم memiliki makna "sangat berat" karena hal itu sudah terlihat dari huruf-huruf yang membentuknya, juga dari urut-urutan hurufnya, juga dari pengucapan harakat-harakatnya. Pengucapan tasydîd pada tsa, dan setelah itu ada mad. Kemudian huruf qaf yang ada unsur qalqalahnya. Sesudah itu diikuti dengan huruf ta yang mengandung hams. Kemudian selanjutnya huruf mîm, yang diucapkan dengan mempertemukan dua bibir, dan suaranya keluar dari hidung.

${ }^{29}$ M. Quraish Shihab, Tafsir Al-Misbah: Pesan, Kesan, dan Keserasian Al-Qur'an (Jakarta: Lentera hati, 2002), 127.

30 Ahmad Mukhtâr 'Umâr, Lughat al-Qur'an., 141. 
Dengan demikian, dalam pengucapannya, menjadi lambat. Dan lambatnya pengucapan ini, memberi kesan makna berat, kesan yang sungguh tepat dengan maknannya. ${ }^{31}$ Ini juga membuktikan bahwa bunyi kata pada ayat di atas, menunjukkan maknanya.

Perhatikan firman Allah di bawah ini

$$
\text { يوم يدعّون الى نار جهنم دعا }
$$

Artinya : "pada hari (ketika) itu mereka di dorong ke neraka jahannam dengan sekuat-kuatnya." (Q.S at-Thur:13).

Pada ayat di atas, tepatnya pada kata يدّا يدّون dan memiliki makna dan kandungan yang sama. Kata الدع mempunyai makna mendorong dari belakang dengan keras, ketika dorongan keras tersebut dilakukan maka akan keluar bunyi yang tidak dikehendaki. Yang bunyi itu menyerupai s. Jadi ini juga membuktikan bahwa bunyi ayat mengisyaratkn pada maknanya. ${ }^{32}$

\section{f) Dalam al-Qur'an ada Kata-Kata Musytarak}

Dalam al-Qur'an, ada dan banyak kata-kata yang musytarak, yaitu satu kata tapi maknanya banyak. ${ }^{33}$ Misalnya kata ولي (walî) dalam al-Qur'an, maknanya tidak hanya satu, tapi memiliki beberapa makna. Ada kata ولي gang bermakna ولد (anak) dalam Q.S. Maryam, ayat 5 berikut:


Maryam: 5)

Artinya "Maka anugrahilah aku anak dari sisimu" (Q.S.

Kata ولي juga bermakna penolong teman tapi yang bukan kerabat. Ini sebagaimana dalam Q.S. al-Isra, ayat 111 .

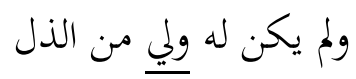

${ }^{31}$ Ahmad Mukhtâr 'Umâr, Lughat al-Qur'an, Dirâsah Tautsiqiyah., 142.

32 Bakrî Syaikh Amîn, al-Ta'bîr al-Fannî fi al-Qur'ân, cet. IV (Kairo: Dâr al-Syurûq, 1980), 181, 182.

33 Penjelasan mengenai Lafazh Musytarak dalam al-Qur'an di antaranya bisa dilihat dalam karya Mahmûd Nûr al-Dîn al-Munjid, al-Isytirâk al-Lafzhy fi al-Qur'ân al-Karîm (Beirut: Dâr al-Fikr al-Mu'âshir, 1999). Lihat juga Muqâtil bin Sulaiman al-Balkhî, al-Mujûh wa al-Nazhâir fi al-Qur'ân al'Azhîm (Dubai: Markaz Jam'ah al-Mâjid li al-Tsaqâfah wa al-Turâts, 2006). Baca juga al-Imâm al-Syaikh Abî 'Abdillah al-Husain bin Muhammad alDâmighânî, al-Wujûh wa al-Nazhâir li Alfâzh Kitâbillah al- 'Aziz (Beirut: Dâr al-Kutub al-'Ilmiah, th) . 

kehinaan."

Artiya: “... Dan tidak memerlukan penolong dari

Kata ولي juga bermakna penolong kerabat dekat. Sebagaimana dalam Q.S. As-Syu'ara, ayat 46 berikut ini

$$
\text { وما كان لهم من اولياء ينصروا فم من دو ن الله }
$$

Artinya: "Dan mereka tidak punya pelindung yang dapat menolong mereka selain Allah".

Kata ولي juga bermakna Tuhan, ini sebagaimana dalam Q.S. al-An'am, ayat 14 berikut ini;

Artinya: قال اغير الله التخدوا ولي menjadika pelindung selain Allah?"

\section{g) Dalam al-Qur'an, ada Kata-Kata yang Diduga Murâdif}

Ulama berbeda pandangan tentang ada tidaknya kata-kata yang maknanya sama dalam bahasa Arab. Itu di dalam bahasa Arab. Tetapi di dalam al-Qur'an, ulama para ahli al-Qur'an mayoritas sepakat bahwa tidak ada kata-kata yang sama maknanya (murâdif) di dalam al-Qur'an, yang ada yang sebenarnya adalah hanya kata-kata yang "diduga" maknanya sama, diduga murâdif..$^{34}$ Kata-kata ini hanya diduga saja sama maknanya, karena setelah diteliti para ulama, ternyata kata yang diduga sama makna, itu sejatinya tidaklah benar benar sama makna, hanya mirip maknanya, tetapi dalam peletakkan atau penggunaannya dalam konteks ayat yang berbeda-beda.

Misalnya saja kata الغيث memiliki arti yang sama yaitu hujan. Keduanya memiliki perbedaan dalam segi pemakaian sesuai kebutuhan. Beberapa perbedaan pendapat mengenai makna المطر dan الغيث bermakna hujan yang datang ketika diperlukan, sedangkan menurut al-Qurthubiy di namakan الغيث karena memenuhi kebutuhan makhluknya. Sementara itu menurut al-Mawardiy, الغيث mengandung arti hujan yang bermanfaat, sedangkan المطر memiliki arti hujan yang tidak hanya bermanfaat tapi juga dapat menimbulkan bencana.

${ }^{34}$ Khâlid Utsman as-Sabt, diterj. Salman Harun, Kaidah-Kaidah Tafsir (Jakarta: PT. Qaf Media Kreativa, 2017), 455-458. 


\section{h) Huruf-Huruf yang Disebut Khusus dan Tepat Makna}

Di antara keunikan bahasa al-Qur'an, adalah adanya huruf-huruf yang digunakan secara khusus, dengan makna yang tepat. Seperti misalnya penggunaan huruf jar / jer pada ayat-ayat al-Qur'an seperti di bawah ini:



Artinya: "Yaitu orang-orang yang lalai terhadap sholatnya."

Penggunaan huruf jar berupa عن ('an) pada ayat di atas lebih tepat dari pada jika menggunakan huruf jar في Jika menggunakan huruf jar i yang berarti "di" atau "di dalam”, maka makna ayat di atas adalah "mereka orang-orang yang lupa hal-hal yang ada di dalam shalat, yang menyebabkan konsekwensi dilakukannya sujud sahwi". Padahal makna yang dikehendaki adalah "mereka orang-orang yang lupa akan shalatnya, yang meninggalkan shalat, atau yang kalau shalat di lama-lamakan, atau mereka yang melaksnakan shalat tapi lupa akan hikmah shalatnya, dengan tetap mengerjakan hal-hal buruk, meski mereka shalat". Karena itu penggunaan huruf jar عن pada ayat di atas, sangat tepat.

Contoh lainnya, perhatikan ayat di bawah ini

$$
\text { ولا تأكلوا أموالهم الى اموالكم }
$$

Artinya: "Dan janganlah kamu makan harta mereka bersama hartamu."

Pada ayat di atas, tidak menggunakan huruf jar 4 atau huruf jar melainkan menggunakan huruf jar الى karena makna yang dikehendaki pada ayat di atas, adalah "jangan makan harta mereka (harta anak-anak yatim) dengan bercampur baur dengan harta kalian". Bila makna ini yang dikehendaki maka huruf jar الي sangat tepat digunakan pada ayat di atas.

\section{i) Penyebutan Mufrad dan Jama' Secara Khusus dalam al- Qur'an}

Dalam bahasa Arab, ada kata-kata yang menunjuk makna jama' (pulral) dan ada kata-kata yang menunjuk makna mufrad (singular). Dalam al-Qur'an, kata-kata yang jama' (plural) dan yang mufrad (singular) digunakan secara khusus dan unik. Tidak setiap yang ada bentuk jama' nya dalam bahasa Arabnya, dalam al-Qur'annya disebut bentuk jama'-nya juga. Tetapi hanya disebut bentuk mufrad-nya juga. 
Di antara contohnya adalah kata الأرض dan lang mana al-Quran menyebutkan kata الأرض yang berarti bumi, selalu menggunakan bentuk mufradnya, dan tidak pernah al-Qur'an menyebutkan kata ini dalam bentuk jama'-nya, الأرضون atau الأرضين . Kalaupun al-Qur'an hendak menyebutkan jama' kata الأرض , maka menyebutkannya dengan ومن الارض مثلهنّ (“...dan seperti itu pula bumi.") (Q.S ath-Thalaq:12).

Sedangkan lawan kata أرض, yaitu kata السماء yang berarti langit, dalam al-Qur'an, disebutkan bentuk jama'-nya dan juga bentuk mufrad-nya. Hanya saja, kapan al-Qur'an menyebutkan dengan bentuk jama' konteks dan maknanya berbeda dengan ketika al-Qur'an menyebutkannya dengan bentuk mufrad. Kata السماء disebut dalam bentuk jama' dalam al-Qur'an untuk menunjukkan makna banyak, sebagaimana dalam Q.S. al- $\underline{\text { Hadîd, }}$ ayat 1 di bawah ini:

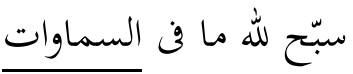
Allah."

Artinya: "Semua yang ada di langit bertasbih kepada

Pada ayat di atas digunakan dalam bentuk jama', untuk menunjukan bahwa yang bertasbih kepada Allah Swt itu semua mahluk yang ada di langit, dan ini artinya banyak. Perhatikan Q.S. adz-Dzâriyat, ayat 22 di bawah ini rezekimu."

Artinya: "Dan di langit terdapat (sebab-sebab)

Pada ayat di atas, digunakan bentuk mufrad, ini bukan hanya bermakna tunggal, tetapi juga untuk menunjukkan arah. Jadi artinya adalah bahwa dari arah langit, dari ataslah, sebabsebab rizkimu. Dalam kitab-kitab tafsir, ada yang menjelaskan bahwa yang dimaksud dengan dari arah langit atau dari ataslah sebab-sebab rizkimu, ini adalah bahwa dari langit turun hujan. Dan air hujan itu menyebabkan bumi dan tanah bisa menumbuhkan tanaman, pohon dan rerumputan, yang kemudian dimakan oleh hewan ternak, dan seterusnya menjadi sumber rizki bagi manusia. 


\section{Rahasia Keunikan dan Keindahan "Susunan Kalimat" dalam al-Qur'an}

Al-Baqilani merinci faktor-faktor keunikan dan keindahan serta kedahsyatan susunan kalimat dalam al-Quran, diantaranya: Pertama, susunan redaksi di dalam al-Qur'an lebih jelas dibandingkan dengan susunan redaksi bahasa arab lainnya. Seperti: saja', syair, khutbah-khutbah, nadham dan surat-surat dalam bahasa Arab. Kedua, Keunikan lainnya, susunan kalimat dalam al-Qur'an berbeda dengan seluruh susunan pembicaraan orang Arab saat itu. Ketiga,al-Qur'an menjadi istimewa karena banyak dan panjangnya, dengan kefasihan yang mutlak serta keindahan susunan kalimat namun tetap terhindar dari kekeliruan, meski tujuan dan cara bacanya berbeda-beda. ${ }^{35}$

Kalimat dalam al-Qur'an memiliki keunikan dan menunjukkan makna yang indah, terutama bila dilihat dari susunan kalimatnya. Sebagai contoh, misalnya dalam penggalan Q.S. at-Taubah ayat 41 yang berbunyi:

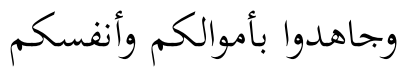

Pada ayat di atas, dikatakan jihad dengan harta (jihâd bi amwâl) disebut lebih dahulu dari jihad mengorbankan jiwa (jihâd bi anfus), padahal dalam keutamaannya, dalam Islam, para ulama sepakat jihad dengan mengorbankan jiwa itu lebih utama derajatnya dari pada mengorbankan jihad mengorbankan harta. Tetapi redaksi pada ayat di atas, kenapa mendahulukan jihad dengan harta daripada jihad mengorbankan jiwa? Ini tentu ada rahasianya. Rahasianya, melalui ayat ini, Allah menyindir orangorang yang tidak mau berjihad mengorbankan harta. Mendahulukan penyebutan jihad mengorbankan harta, ini adalah sindirian, bahwa mari berjihad dengan harta, berjihad dengan harta saja berat, apalagi mau berjihad dengan mengorbankan jiwa? Ini adalah sindiran luar biasa, agar orang-orang mau berjihad.

Contoh kedua, yang menunjukkan keunikan dan keindahan susunan kalimat dalam al-Qur'an, adalah sebagaimana dalam dalam Q.S. Ali-Imran ayat 97 yang berbunyi:



35 'Abd al-Qâdir Husain, al-Qur'ân: I'jâzuhu wa Balâghatuhu (Kairo: al-Amânah, 1975), 108. 
Artinya: "Dan diantara kewajiban manusia terhadap Allah adalah melaksanakan ibadah haji ke Baitullah, yaitu bagi orang-orang yang mampu melakukan perjalanan ke sana."

Ayat di atas, menyampaikan tentang kewajiban berhaji bagi mereka yang mampu. Sebenarnya bisa saja Allah menyampaikan kewajiban itu dengan menyeru "Wahai orangorang beriman, pergilah ke Baitullah untuk berhaji" (Yâ ayyuha al-ladzîna âmanû idzhabû ilâ baitillah hajjan). Tetapi pada ayat di atas, kewajiban haji itu disampaikan mula-mula dengan wa lillahi, artinya haji itu harus diniatkan untuk beribadah kepada Allah $^{36}$, haji itu bukan untuk kepentingan selain ibadah, bukan untuk kepentingan pencitraan, bukan untuk rekreasi atau jalanjalan, bukan untuk meningkatkan status sosial atau untuk keperluan bisnis, haji hanya untuk beribadah kepada Allah. Maka dari itu jelas sekali redaksinya wa lillahi. Redaksi al-Qur'an yang demikian, ini sangat tepat, karena dalam beberapa kasus, di masyarakat, kenyataannya haji bukan hanya dimaknai ibadah, tetapi berbagai kepentingan lainnya. Kewajiban ibadah ini ditunjukkan kepada manusia ('ala an-nâs) secara umum, tetapi kemudian dibatasi hanya mereka yang mampu (man istathâ'a). Dengan ayat di atas Allah mewajibkan haji, tetapi coba lihat susunan kalimatnya, unik, indah dan mengena di jiwa dan sesuai kenyataan.

Contoh berikutnya, perhatikan Q.S. Yusuf, ayat 85 di bawah ini:

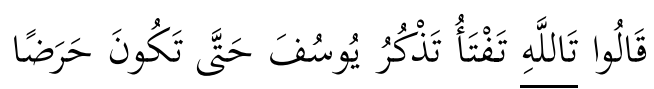

Artinya: "Mereka berkata, demi Allah, engkau tidak henti-hentinya mengingat Yusuf sehingga engkau mengidap penyakit berat"

Pada ayat di atas, terdapat huruf qasam (huruf yang digunakan untuk sumpah) berupa «lا». Sebagaimana kita ketahui bahwa huruf qasam itu ada tiga, waw, ba, dan ta'. Bila bersumpah dengan waw qasam maka kekuatan sumpahnya paling kuat. Setelah itu, sumpah yang menggunakan ba qasam, nilai kekuatan sumpahnya menengah, sementara sumpah yang menggunakan ta' qasam maka nilai sumpahnya paling rendah.

${ }^{36}$ Muhammad Rawwas Qal'ahji, Lughat al-Qur'ân Lughat al-'Arab alMukhtârah, h. 71 
Karena sumpah itu dari saudara-saudara Nabi Yusuf as. yang telah berbohong kepada nabi Ya'qub, maka kekuatan sumpahnya pun tidak kuat. Karena itulah yang dipakai adalah huruf qasam berupa $t a{ }^{37}$

Keindahan susunan kalimat dalam al-Qur'an, di antaranya juga dibuktikan pada ayat di bawah ini, Q.S. Hûd, ayat 44, silahkan diperhatikan:

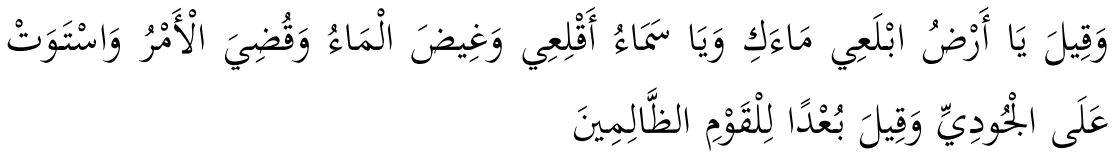

Artinya: "Dan difirmankan, 'wahai bumi! Telanlah airmu dan wahai langit (hujan) berhentilah. ' dan airpun disurutkan, dan perintahpun diselesaikan dan kapal itu pun berlabuh diatas gunung Judi, dan dikatakan, ' binasalah orang-orang yang dholim."

Pada ayat di atas, Allah memanggil al-Ardhu (bumi) dengan huruf nidâ, yaitu ya'. Sedangkan huruf nidâ ya' adalah seruan bagi makhluk hidup yang berakal. Hal ini mengisyaratkan bahwa bumi dianggap memiliki tubuh dan Allah memberinya sifat berakal, lagi menjadikannya mendengar dan memiliki kesadaran. Demikian, Allah menerangkan bahwa semua makhluk di hadapan Allah itu sama. Allah adalah sang pencipta, ia bisa berhadapan dengan semua makhluknya, seperti bumi dan langit yang bisa diajak bicara oleh-Nya, mendengar dan patuh terhadapNya.

Pada ayat di atas, penggunaan kata Abla'iy, dan bukan yang lain, seperti asyribiy, ini karena kata yang kedua itu artinya hanya minumlah, sementara kata abla'iy, berarti perintah untuk menelan air secara cepat dalam jumlah yang banyak. Selanjutnya, digunakan Abla'iy mâ'aki (telanlah/seraplah airmu) ..dan tidak digunakann susunan Abla'il Mâ (seraplah air)...Tentu saja, perintah "Seraplah/telanlah airmu" lebih kuat daripada "seraplah air/telanlah air". Kemudian Allah menyeru kepada langit, sebagaimana Allah telah menyeru pada bumi...Yaa samâ'u aqli'iy (wahai langit, hentikan hujan). Setelah Allah memerintah pada bumi untuk menyerap air banjir, agar banjir segera redah, dan setelah Allah memerintahkan langit untuk menghentikan hujan, kemudian wa ghiidh al-maa'u (air diserapkan).

\footnotetext{
${ }^{37}$ Ahmad Mukhtâr 'Umâr, Lughat al-Qur'an, Dirâsah Tautsiqiyah., 169.
} 
Bila awalnya menggunakan redaksi amr (perintah), amr (perintah) pada bumi dan langit, tapi kemudian pada "wa ghidh al-mâ'u" diungkapkan dalam bentuk mabni majhuul, yang artinya, fa'il nya (subyeknya) tidak disebutkan, ini sebenarnya fa'ilnya (subyeknya) adalah Allah, jadi yang menyerpakan air banjir itu hakikatnya adalah Allah. Meskipun bumi sudah menghentikan banjir, langit menghentikan hujan, tetapi bencana banjir, hanya reda, bila dikehendaki Allah Swt. ${ }^{38}$ Sungguh susunan kalimat yang sangat mantap, indah dan tepat maknanya. Di antara bentuk keindahan susunan kalimat dalam al-Qur'an, juga di antaranya, ada ayat-ayat yang susunan redaksinya miripmirip saja, dan hanya beda di beberapa bagian saja. Meskipun sangat mirip, dan berbeda di beberapa bagian saja, ternyata makna dan peruntukan ayatnya berbeda. Ini sebagaimana dalam dua ayat yang mirip di bawah ini;



Artinya: "Janganlah membunuh anak-anakmu karena miskin, kamilah yang memberi rizki kepadamu dan kepada mereka." (QS. al-An'am[6]: 151).



Artinya: "Dan janganlah kamu membunuh anakmu karena takut miskin, kamilah yang memberi rizki kepada mereka dan kepadamu." (QS. al-Isra'[17]: 31).

Perhatikan dua ayat di atas. Pada ayat pertama, dhamîr kum (untuk orang tua) didahulukan dari pada dhamîr hum (untuk anak-anaknya). Karena ayat yang pertama di atas, ditunjukan kepada orang miskin yang hidup dengan sangat kekurangan. Mereka membunuh anak-anak mereka karena tidak mampu memberi makan anak-anaknya. Oleh karena itu, pada ayat pertama di atas, Allah menjamin rizki bagi kedua orang tuanya terlebih dahulu, setelah itu rizki bagi anak-anaknya. Semenatara pada ada ayat kedua di atas, dhamîr hum (untuk anak-anaknya) didahulukan dari pada dhamîr kum untuk orang tua. Karena ayat kedua di atas, ditunjukan kepada orang tua yang kaya yang hidup dalam kemewahan tetapi takut suatu hari mereka jatuh miskin. Oleh karena itu, Allah menjamin rizki anak-anak mereka, sehingga mereka tidak takut akan kemiskinan sebab kehadiran anak mereka.

38 ‘Abd al-Qâhir al-Jurjânî, Dalâil al-I’jâz (Damaskus: Tp, 1987), 91-92. 
Selain itu lafazh min pada ayat pertama di atas, menunjukan makna li ajli (karena) dan menunjukan waktu saat ini. Sedngkan lafazh khasyah menunjukan makna takut namun pada waktu yang akan datang. ${ }^{39}$ Bahkan jika ada ayat-ayat yang mirip redaksinya, lalu satu ayat al-Qur'an di antara yang mirip ini, susunan redaksi kalimatnya terasa tidak serasi, terkesan todak serasi, tetapi setelah diteliti, maka kita akan tahu ternyata yang terkesan susunan kalimatnya tidak serasipun, seseungguhnya merupakan susunan kalimat yang serasi. Ini sebagaimana Q.S. alAn'am, ayat 95 di bawah ini.

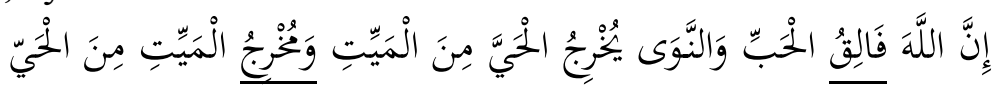

Artinya: "Sesungguhnya Allah yang menumbuhkan butir (padi-padian) dan biji (kurma). Dia mengeluarkan yang hidup dari yang mati dan mengeluarkan yang mati dari yang hidup."

Pada ayat di atas, bila dibandingkan dengan dua ayat lain yang beredaksi mirip dengan ayat di atas, maka sekilas akan terasa ada yang janggal. Yaitu Q.S. Ali Imran, ayat 27 dan Q.S. ar-Rûm, ayat 19. Di mana pada dua ayat ini redaksinya terkesan



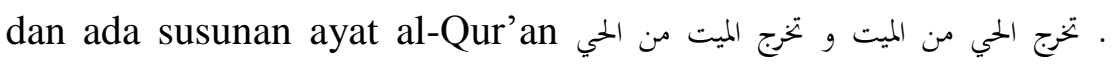
Adapun susunan ayat di atas baru bisa itu tetap serasi susunan kalimatnya, bila dijelaskan oleh ulama, seperti di bawah ini.

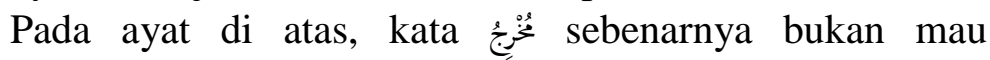
mengimbangi kata sebelumnya, يخرج. Akan tetapi kata yang

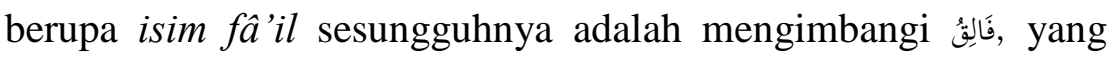
juga bentuk isim fầil. Selain itu, pada ayat di atas, kata $a l-\underline{h} a b b u$ dan an-nawa, artinya sama, biji-bijian. Bedanya, kata al-habbu, artinya biji-bijian yang untuk makanan pokok suatu negeri, sedangkan an-nawa, yang bukan makanan pokok. Karenanya pada ayat di atas, Allah mendahulukan, kata al-habbu dari pada kata an-nawa. ${ }^{40}$ Sifat biji-bijian tanaman, adalah bisa tumbuh, atau bisa bertunas, siapa sesungguhnya yang menumbuhkan tunasnya itu dari biji-bijian itu? Allah, karena itu pada ayat di atas dikatakan.

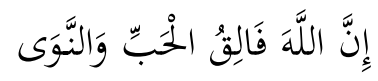

${ }^{39}$ Bakri Syaikh Amîn, al-Ta'bîr al-Fannî fi al-Qur'ân (Tp: Dâr alSyurûq, 1980), 190. 172.

An Ahmad Mukhtâr 'Umâr, Lughat al-Qur'an, Dirâsah Tautsiqiyah., 


\section{Rahasia Kekuatan dan Keindahan "Penggambaran" dalam al-Qur'an}

Kalimat dalam al-Qur'an, bukan hanya unik, khas dan indah susunannya, tetapi juga mengandung penggambaran yang baik dan luar biasa, sehingga meskipun al-Qur'an itu berupa rangkaian kata dan susunan kalimat saja, tetapi karena susunan kalimatnya yang indah sempurna, maka mengandung penggambaran, yang menyebabkan para pembaca atau para pendengar al-Qur'an, bisa menggambarkan bisa membayangkan apa yang dideskripsikan ayat-ayat al-Qur'an.

Sebagai contoh, misalnya saja penggambaran tentang buruknya perbuatan ghibah dalam penggalan Q.S. al-Hujurat, ayat 12 ;

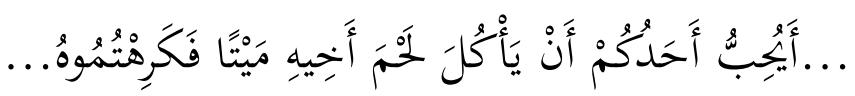

Artinya: "Apakah ada di antara kamu yang suka memakan daging saudaranya yang sudah mati? Tentu kamu merasa jijik"

Ayat di atas sebenarnya mengabarkan bahwa melakukan ghibah (menggunjing orang lain) itu perbuatan buruk dan tercela. Pada ayat di atas tentang buruknya ghibah digambarkan dengan sangat tepat dan mengena. Orang yang menggunjing orang lain (melakukan ghibah), digambarkan seperti orang yang makan daging saudaranya yang sudah jadi bangkai.

Pertama, orang yang melakukan ghibah dinyatakan seperti makan daging, bukan sembarang daging, tapi daging saudaranya sendiri. Ini memberi kesan sangat kejam perbuatan ghibah tersebut. Ditambah lagi, daging saudara yang dimakan itu adalah yang sudah jadi mayat, ini bukan hanya memberi kesan kejam, tetapi juga menjijikkan. Sehingga, kalau sadar akan kejam dan jijiknya perbuatan ghhibah, melalui penggambaran sebagaimana ayat di atas, orang akan benci dan menjauhi ghibah. 
Penggambaran-penggambaran yang mengena seperti di atas, banyak terdapat dalam al-Qur'an. Misalnya saja penggambaran-penggambaran kedahsyatan dan kengerian hari kiamat. Al-Qur'an menggambarkan kedahsyatan dan kengerian hari kiamat, dengan sangat hebat, dhsyat tak terkira, ngeri tak terperi.

Tentang hal ini, ada ulama kenamaan, Sayyid Quthb yang menuliskan tentang kedhasyatan hari kiamat dalam sebuah karya yang berjudul Masyâhid al-Qiyâmah fì al-Qur'ân. ${ }^{41}$

Dalam kitab Masyâhid al-Qiyâmah, di antaranya disampaikan contoh tentang penggambaran hari kiamat pada Q.S. Abasa ayat 34 yang berbunyi:

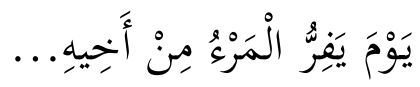

Pada ayat di atas digambarkan bawah nanti jika terjadi hari kiamat, maka seseorang (al-mar'u) akan lari dari saudaranya, lari dari sahabat-sahabatnya, lari dari anak-anaknya, lari dari ibu bapaknya. Ketika terjadi bencana, biasanya seseorang akan mencari orang-orang terdekatnya, mencari istri dan anaknya, mencari ibu bapaknya, mencari saudara dan sahabatnya. Misalnya saja, ketika terjadi bencana Tsunami di Aceh pada 2004 yang silam, maka diberitakan masing-masing orang akan mencari saudara dan orang-orang terdekatnya. Sementara pada ayat di atas, justru digambarkan sebaliknya, ketika terjadi kiamat, orang akan sibuk dengan diri mereka masing-masing, dan tidak sempat lagi memperhatikan keluarga dan orang-orang dekatnya, ini penggambaran tentang kiamat yang sangat dahsyat dan mengerikan.

Kengerian dan kedahsyatan hari kiamat, di antaranya juga digambarkan dalam Q.S. al-

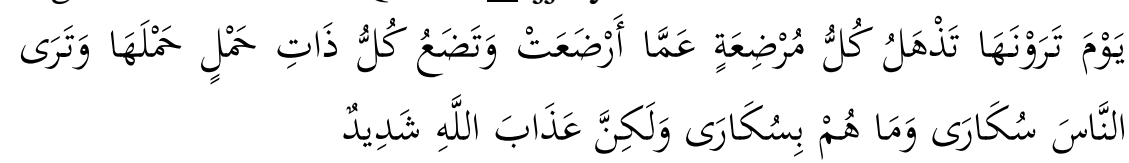

Artinya: "(ingatlah) pada hari ketika kamu melihatnya (guncangan itu), semua perempuan yang menyusui anaknya akan lalai terhadap ayat yang disusuinya, dan setiap perempuan yang hamil akan keguguran kandungannya, dan kamu melihat manusia dalam keadaan mabuk, padahal sebenarnya mereka tidak mabuk, tetapi azab Allah itu sangat keras."

${ }^{41}$ Sayyid Quthb, Masyâhid al-Qiyâmah fi al-Qur'ân, cet. XVI (Kairo: Dâr al-Syurûq,2006). 
Sebelum mengomentari penggambaran tentang hari kiamat pada ayat di atas, mari kita ingat pada beberapa tahun yang lalun, sekitar 2010 dan 2011, ada beredar film "Kiamat 2012". Sesuai judulnya, film ini menceritakan dan memviasualisasikan kedahsyatan kiamat dunia yang diprediksi terjadi tahun 2012.

Digambarkan dalam film tersebut, bagaimana air laut naik ke daratan, meelan kota-kota dengan gedung-gedung tingginya. Gempa dan gunung meletus terjadi di mana-mana, semua dunia dengan segala keindahannya, kota-kota yang mewah, rusak semua, hutan, gunung, lautan hancur lebur, berhamburan, tercerai berai. Manusia menjerit, berlari-lari ketakutan. Penonton dibikin terkesima dengan adegan-adegan kengerian kiamat pada film ini. Akan tetapi penggambaran kedahsyatan kiamat di Film Kiamat 2012 ini tidak lebih hebat dengan yang ada dalam al-Qur'an, sperti ayat di atas misalnya. Dalam ayat di atas, digambarkan bahwa kedahsyatan hari kiamat, itu menyebabkann ibu-ibu yang sedang menyusui bayinya, akan melepas bayinya. Di mana-mana, kalau terjadi bencana, seorang ibu akan mencari anaknya, akan mendekap bayinya erat-erat. Tetapi al-Qur'an menggambarkan bahwa kengerian hari kiamat menyebabkan ibu menyusui lupa akan bayinya, sungguh mengerikan. Bahkan, ayat di atas juga menggambarkan, nanti jika terjadi hari kiaat yang menggelegar itu, ibu yang hamil, akan langsung keguguran, karena tidak kuat menahan rasa takut dan ngeri menghadapi kiamat. Sungguh penggambaran yang luar biasa. 


\section{Rahasia Keunikan dan Keindahan "Bunyi" dalam al- Qur'an}

Ahmad Mukhtar Umar, menyatakan bahwa keunikan dan keindahan bunyi dalam al-Qur'an, setidaknya meliputi tiga hal berikut: (1) Keunikan bacaan al-Qur'an; (2) Keserasian Susunan Nada; (3) Keunikan yang ada pada al-Faashilah al-Qur'aniyah ${ }^{42}$.

\section{a) Keunikan Bacaan}

Imam al-Qasthalâni dalam kitab Lathâif al-Isyârat li Funûn al-Qira'ât ${ }^{43}$, mengatakan bahwa, di antara keunikan bacaan al-Qur'an adalah bahwa membacanya harus dengan Tajwîd, dengan memperhatikan makhârij al- $\underline{h} u r u \hat{f} f$, memberikan dan memenuhi hak-hak huruf-huruf itu tanpa harus melebihlebihkan dan menguranginya. Sungguh di antara keunikan juga membaca dengan mengetahui segala aturan Tajwîd yang ada.

Selain membacanya, harus dengan Tajwîd, sebaiknya kita membaca al-Qur'an dengan memperindah suara sebagaimana yang telah diriwayatkan oleh Ibnu Hibban dalam Shohihnya Rasulullah Saw telah bersabda:

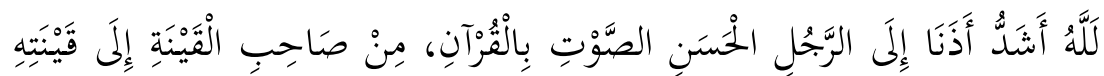

$$
\begin{aligned}
& \text { (رواه ابن حبان في صحيحه, ج 3, ص 31 31) }
\end{aligned}
$$

Artinya: "Allah sangat suka mendengar sesorang yang membaca al-Qur'an dengan suara merdu, dari pada mendengar nyanyian penyanyi" (H.R. Ibnu Hibbân)

Imam Bukhori juga meriwayatkan bahwa Ibnu Mas'ud termasuk orang yang bagus bacaan al-Qur'annya. Rasulullah Saw. pernah meneteskan air mata ketika mendengar bacaan Ibnu Mas'ud $^{44}$. Dan diperbolehkan membaca Al-Qur`an dengan penuh penghayatan sehingga mampu menggetarkan hati, menitihkan air mata, menimbulkan rasa takut, hingga pesan al-Qur`an mudah diterima jiwa.

${ }^{42}$ Ahmad Mukhtâr 'Umâr, Lughat al-Qur'an, Dirâsah Tautsiqiyah., 128.

43 Al-Qathalâni, Lathâ'if al-Isyârah li Funûn al-Qira'ât, jilid 1 (Madinah: Wuzârah al-Syu'ûn al-Islâmiyah wa al-Auqâf, wa al-Da'wah wa alIrsyâd, th), 207.

${ }^{44}$ Al-Qathalâni, Lathâ' 'if al-Isyârah li Funûn al-Qira'ât., 210. 
Tetapi itu semua dengan syaratn tetap memtahui aturan Tajwîd, seperti: (1) Ketika membaca al-Qur'an, tetap menjaga makhârij al-hurûf; (2) Tidak melanggar batas-batas aturan dengan memanjang-manjangkan lagu; (3) Tidak berlebihan atau telalu minimal dalam hal mad; (4) Tidak salah membaca harakat; (5) Tidak mempraktekan idghâm bukan pada tempatnya.

Dalam hal ini para ulama mengatakan bahwa, cara jibril mengajarkan al-Qur`an pada Nabi Muhammad Saw. hendaklah diikuti umatnya. Yaitu belajar membaca al-Qur'an dengan tartîl sesuai tajwîd kepada para syeikh ahli qira'at (ahli al-Qur`an) secara talaqqi syafahi.

Di samping itu, untuk membaca al-Qur'an dengan benar kita harus mengetahui hukum waqaf dengan benar. Al-Qasthalani berkata; "Para qâri membutuhkan pengetahuan tentang waqaf sebagaimana manusia membutuhkan nafas, karena baik buruknya suatu bacaan tergantung pada waqaf." mendefinisikan waqaf dengan "menghentikan suara sejenak untuk mengambil nafas denga niat melanjutkan bacaan". Mengetahui waqaf sangat penting untuk memudahkan pemahaman terhadap makna ayat. Abu Hatim berkata; "Orang yang tidak mengetahui hukum waqaf, ia tidak akan memahami alQur`an.”. Milsanya pada ayat di bawah ini;

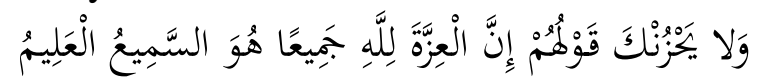

Artinya: "Janganlah kamu sedih oleh perkataan mereka. Sesungguhnya kekuasaan itu seluruhnya adalah kepunyaan Allah. Dialah Yang Maha Mendengar lagi Maha Mengetahui."

Jika pada ayat di atas, kita tidak waqaf pada kalimat قولم akan terjadi kerancuan dalam maknanya. Karena bila tanpa waqaf di قولم maka maknanya bisa saja dipahami berikut; "Janganlah kamu sedih oleh perkataan mereka yang mengatakan bahwa sesungguhnya kekuasaan itu seluruhnya adalah kepunyaan Allah., Dialah Yang Maha Mendengar lagi Maha Mengetahui,"46.

\footnotetext{
${ }^{45}$ Al-Qathalâni, Lathâ 'if al-Isyârah li Funûn al-Qira'ât., 247.

${ }^{46}$ Al-Qathalâni, Lathâ 'if al-Isyârah li Funûn al-Qira'ât., 251
} 


\section{b) Keserasian Susunan Bunyi/Nada}

Menurut al-Zarqâni, yang dimaksud dengan keserasian dalam tata bunyi Al-Qur`an adalah keserasian dalam pengaturan tanda baca (seperti a, i, dan u), sukun, mad, gunnah, sehingga enak untuk didengar dan diresap dalam jiwa yang itu tidak mungkin tertandingi oleh ungkapan-ungkapan lain, semisal puisi atau prosa ${ }^{47}$

Menurut ar-Rafi'i, keserasian bunyi al-Qur'an terletak pada keserasian penempatan huruf-huruf sesuai keindahan buntinya, baik hams, jahr, qalqalah, shafìr, mad, ghunnah, dan lainnya ${ }^{48}$. Ar-Rûmâni, ulama dari abad $4 \mathrm{H}$, membagi pembicaraan, pada tiga tingkatan. Tingkat tererndah adalah pembicaraan yang rancu. Tingkat kedua, pembicaraan serasi dan indah tingkat sedang. Tingkat ketiga, pembicaraan yang sangat serasi dan sangat indah. Dalam hal ini, Ar-Rumani menegaskan, bahwa tingkat tertinggi keserasian pembicaraan, ada pada alQur'an, dari awal sampai akhir, al-Qur'ann sangat serasi. Ini karena adanya keseimbangan pada huruf-huruf dan susunannya. ${ }^{49}$

Keserasian suara dalam al-Qur`an juga meliputi susunan kata-katanya dan keseimbangan suaranya, juga memiliki sifat mudahh diucapkan. Di antara keseimbangan surah adalah apa yang ada dalam Fawâtih al-Suwâr. Oleh karena itu, al-Baqilani dalam kitabnya yang berjudul I'jaz al-Qur'an; "Sesunguhnya yang membentuk perkataan orang Arab (ㅂurûf Hijâiyah) itu adalah 29 huruf $^{50}$, dan jumlah surat yang dibuka dengan hurûf hijâiyah, tepatnya dibuka dengan huruf-huruf muqatha'ah itu ada 29 surat. Sedangkan huruf-huruf yang menjadi pembuka suratsurat itu jumlahnya adalah hampir setengahnya jumlah surat-surat tersebut, yaitu 14 huruf. $^{51,}$

${ }^{47}$ Al-Zarqâni, Manahil al- 'Irfân fi 'Ulûm al -Qur'ân (Beirut: Dâr Ihya' al-Kutub al-'Ilmiyah:, 2004), 446.

${ }^{48}$ Al-Bâqilânî, I'jâzz al-Qur'ân (Kairo: Dâr al-Ma'ârif, 1963), 218. 87-89.

${ }^{49}$ Ar-Rumani, al-Nukat fí I'jâz al-Qur'ân (Kairo: Dâr al-Ma'ârif, 1976)

${ }^{50}$ Pendapat yang masyhur mengatatakan bahwa Huruf Hijaiyah itu bukan 29 hruf, tetapi 28, karena tidak menghitung huruf alif.

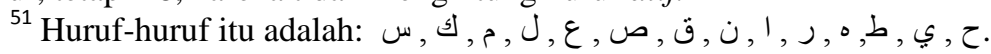


Al-Baqilani juga berkata: "Para ulama membagi hurûf hijâiyah pembuka surat-surat (fawâtih_suwâr) tersebut sebagian merupakan huruf-huruf hams dan sebagian ada huruf-huruf jahr. Keseimbangan dan keserasian bisa juga dilihat sebagai berikut: Ada yang disebut dengan huruf-huruf halqi, huruf-huruf syiddah, dan huruf-huruf al-muthabaqah atau thibaq.

Yang menarik adalah, sebagian dari kelompok huruf itu masing-masing adalah termasuk Fawâtih Suwâr. Huruf halqi, yang terdiri dari 6 huruf, sebagiannya, 3 di antaranya adalah Fawâtih Suwâr, yaitu se Sementara huruf-huruf syiddah, yang tergabung dalam أجدت طعقك هe ada 8 huruf, 4 di antaranya adalah Fawâtih Suwâr, yaitu, s, s, , , , Sedang huruf-huruf muthabaqah/thibaq, yang berjumlah 4, terdiri dari, , , , , , 2 diantaranya, adalah Fawâtih Suwâr, yaitu b dan ص. Sungguh ini semua jelas sekali menunjukkan keluarbiasaan al-Qur`an dan keluarbiasaaan ini menunjukkan bahwa al-Qur'an itu berasal dari Maha Luar Biasa, Allah Swt. ${ }^{52}$

${ }^{52}$ Al-Bâqilânî, I'jâz al-Qur'ân., 70-80. Tentang kemu'jizatan al-Qur'an, dalam bentuk hitung-hitungan juga di antaranya dikaji oleh intelektual muslim kenamaan, Rasyad Khalifah, yang mengkaji huruf shâd dalam surah shâd, juga mengkaji huruf qâf dalam surah qâf, dan nûn dalam surah al-Qalam. 


\section{c) Al-Fâshilah al-Qur âniyah}

Al-Fâshilah adalah kata yang berada di akhir ayat, sebagian ulama menyebutnya Ra'su al-Ayat. Al-Qur'an sangat menjaga keserasian al-Fâshilah al-Qur'âniyah, demi menjaga keindahan susunan bunyinya. Al-Fâshilah al-Qur'âniyah bila dalam sya'ir Arab, ini menyerupai al-qâfiyah dan bila dalam prosa Arab (natsr), ini menyerupai saja' (sajak) akhir kalimat. ${ }^{53}$

Selain itu ada kebiasaan bangsa Arab, mereka selalu mengakhiri setiap bait syairnya dengan huruf mad dan nûn. Imam Sibawaih mengatakan bahwa; "Orang-orang Arab bila bersnandung atau menyanyi maka untuk memanjang-manjangkan suara dengan menggunakan huruf alif, yâ, wauw ${ }^{54}$. Lalu disandarkan dengan huruf mîm dan nûn, karena dua huruf ini sama-sama huruf yang sama sifatnya, yaitu bersifat ghunnah dan keluar suara mîm dan nûn, yang enak untuk dinyanyikan dan diulang-ulang. ${ }^{55}$

Dalam konteks ini, maka kita bisa sebut misalnya saja surat al-Baqarah yang terdiri dari 286 ayat. Dimana 192 ayatnya selalu diakhiri dengan huruf nûn, dan 54 ayat lainnya diakhiri dengan huruf mîm. Sedangkan surah an-Nisâ, yang terdiri dari 176 ayat, 56 ayatnya diakhiri dengan mîm, dan yang diakhiri dengan $\mathrm{ra}$ ada 33 ayat. Yang diakhiri dengan lam, ada 28 ayat, dan yang diakhiri dengan nûn ada 17 ayat.

53 Banyak ulama keberatan penggunaan kata "saja”" (sajak), untuk akhir ayat dalam al-Qur'an, dengan tujuan agar al-Qur'an tidak disamakan dengan saja' (sajak) pada mantra-mantra para dukun (kuhân). Karrena itu istilahh yang di gnakan untuk menunjuk akhir ayat pada al-Qur'an adalah "alFâshilah”. Berbeda dengan ulama kebanyakan, Ibnu Sinân dalam kitab Sirr al-Fashâhah, menyatakan bahwa sebenarnya tidak ada perbedaan antara saja' dan fâshilah. Menurutnya baik saja' maupun fâshilah sama-sama merupakan kesamaan atau kemiripan bunyi akhir kalimat. Ini enak diucapkan dan enak didengar. Di antara letak kefasihan dan keindahan al-Qur'an adalah terletak pada keserasian bunyi akhir ini. Lihat az-Zarkâsyi, al-Burhân fi Ulûm alQur'an, jilid 1, 35 dan 54. As-Suyûthi, al-Itqân fi Ulûm al-Qur'ân, jilid 2, cet. III (TK: al-Halabi, 1951), 96- 98. Lihat 'Aisyah 'Abd ar-Rahmân Bint alSyâthi', I'jâz al-Bayân li al-Qur'ân (Kairo: Dâr al-Ma'ârif, 1971), 235. Baca Muhammad al-Hasnâwî, al-Fâshilah fi al-Qur'ân (Beirut: Tp, 1986)

${ }^{54}$ As-Suyuthi, al-Itqân fi Ulûm al-Qur'ân, jilid 2, 105.

55 Akhir ayat atau al-Fâshilah al-Qur'âniyah yang dikahiri dengan huruf nûn ada 3152, yang dikahiri dengan huruf mîm ada 742, yang diakhiri dengan huruf $\mathrm{ra}$ ada 710, yang diakhiri dengan huruf dâl ada 308, yang diakhiri dengan huruf yâ ada 245, yang diakri dengan huruf $b a$ ada 221, yang diakhiri dengan huruf lâm ada 211..dan seterusnya. Lihat Muhammad alHasnâwî, al-Fâshilah., 296. 
Dalam surah Ali Imron dan surah al-Maidah, bunyi akhir ayat didominasi oleh nûn, baru kemudian oleh mîm. Surah ArRahman terdiri dari 78 ayat. Dimana 69 ayatnya diakhiri dengan huruf nûn, 7 ayatnya diakhiri dengan mim, dan 2 ayat sisanya diakhiri dengan huruf $r a$.

Di samping itu, contoh-contoh di bawah ini, menunjukkan betapa al-Qur'an sangat menjaga keserasaian bunyi akhir ayatayatnya. Berikut ini contoh-contohnya; Pertama, penggunaan Taqdîm Ta'khîr, yakni mendahulukan yang seharusnya di akhir. Sebagaimana cotohnya, penyebutan Harun lebih didhaulukan dan penyebutan Musa diakhirkan pada Q.S. Thaha, ayat 70 berikut:

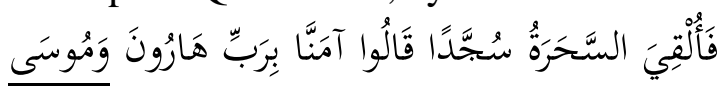

Dalam ayat ini Musa diakhirkan supaya akhir ayat berupa hurûf alif yang menjadi karaktristik surat ini. Dalam ayat yang lain justru sebaliknya, sebagaimana dalam ayat Q.S. as-Syu'ara, ayat 47 dan 48 berikut ini:

$$
\begin{aligned}
& \text { قَالُوا آمَنَّا بِرَبِّ الْعَالَمِينَ } \\
& \text { رَبِّ مُوسَى وَهَهارُونَ }
\end{aligned}
$$

Pada ayat di atas Musa didahulukan dari pada Harun, sebab untuk menjaga keserasian dengan akhir ayat lainnya. Karena kata-kata akhir ayat atau al-Fâshilah sebelum dua ayat di atas adalah ghâlibûn, ya'fikûn, sâjidîn.

Kedua, penambahan huruf untuk menjaga Fâshilah, Q.S. al-Ahzab ayat 10

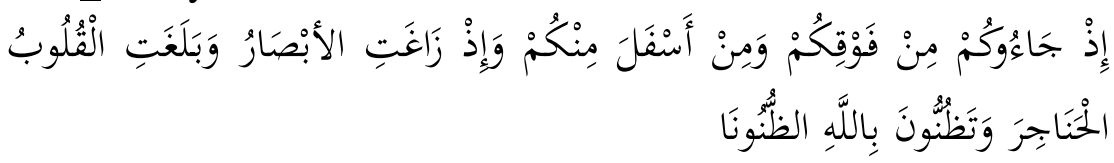

Alif yang ada pada kata الظنونا bukan asli, tetapi hanya tambahan, karena untuk menyerasikan akhir ayat. Ayat sebelumnya berbunyi:

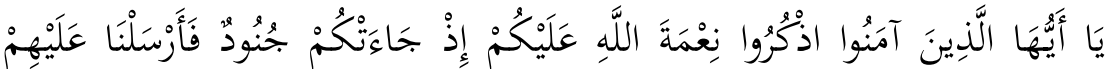



Ayat setelahnya berbunyi:

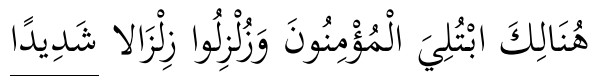

Alif yang ada pada kata بصير dan شديدا adah alif yang mengganti tanwin ketika waqaf (tanwîn 'iwâdh) 
Ketiga, menghilangkan huruf ya 'illat, demi menjaga keserasian akhir ayat. Ini sebagaimana dalam QS. Al-Fajr

$$
\text { وَاللَّنْلِ إِذَا يَسْرِ }
$$

Pada ayat di atas, يسري asalnya يسر. Huruf ya 'illat dibuang karena untuk menyerasikan akhir ayat ini dengan ayat sebelum dan sesudahnya.

Keempat, untuk tujuan menserasikan bunyi akhir ayat, kadang dalam al-Qur'an dimunsharifkan (diberi tanwîn) kata yang tidak munsharif (tidak menerima tanwîn) . Ini sebagaimana dalam Q.S. al-Insân ayat 15 berikut:



Kata قوارير alifnya adalah tambahan. Asalnya kata tersebut tidak ada alif-nya, karena alif tersebut menjadi gantinya tanwin ketika waqaf. Sedangkan kata قواري merupakan kata yang tidak menerima tanwin karena termasuk sighat muntahal jumû̉. Alif tersebut ditambahkan untuk menyerasikan dengan ayat sebelumnya dan sesudahnya. Ayat sebelumnya adalah:



Sedangakan ayat setelahnya adalah:

$$
\text { قَوَارِيرَ مِنْ فِضَّةِ قَدََّروهَا تَقْدِيرًا }
$$

Kelima, menghilangkan huruf Kaf Dhamîr Mukhoahab, untuk menserasikan bunyi akhir ayat. Perhatikan, berikut di bawah ini Q.S. Ad-Dhuhâa, ayat 1-8:

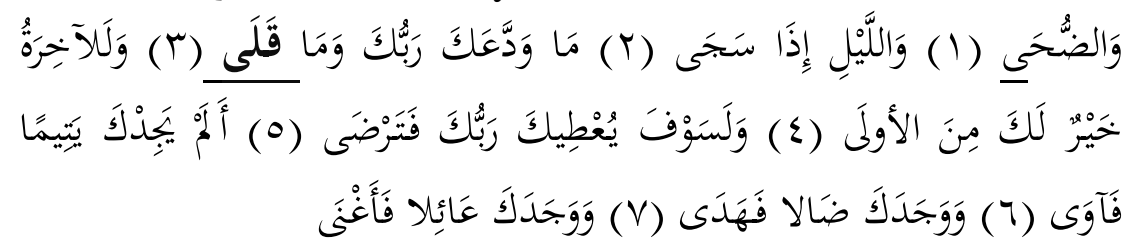

Pembuangan huruf Kaf Dhamîr pada surat ad-Dhuhâ ayat 3 di atas, itu demi keserasaian bunyi akhir ayat, agar sesuai dengan bunyi ayat sebelumnya dan bunyi ayat sesudahnya, dan dengan demikian bunyi akhir ayat-ayat pada surah ad-Dhuhâ di atas menjadi serasi nada bunyinya. Meskipun demikian, pembuangan huruf Kaf Dhamîr pada surat ad-Dhuhâa ayat 3, sesungguhnya tidak hanya untuk menjaga keserasian akhir ayat semata, namun mengandung hikmah yang sangat tinggi. 
Diantaranya jika kata قلَ menggunakan s maka akan menimbulkan kesan bahwa Allah hanya mengkhususkan kebencian itu kepada Nabi Muhammad Saw.

Keenam, kata Jama' yang ditulis dengan bentuk Mufrodnya atau sebaliknya. Contoh: QS. Al-baqarah ayat 54.

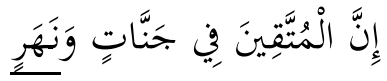

Kata أهار akan tetapi ditulis dalam bentuk mufrad karena untuk menjaga keserasian akhir ayat dengan akhir ayat sebelum dan sesudahnya. Sebaliknya, di bawah ini contoh penyebutan kata mufrad ditulis jama':

$$
\text { لا بَيْعُ فِيِهِ وَلا خِلالِ }
$$

Kata خلال adalah jama', pada daasrnya berbentuk mufrad yaitu ditulis jama' untuk menyerasikan dengan akhir ayat sebelum dan setelahnya.

Ketujuh, penggunaan shigat mudhâri' pada mahal shigat mâdhi. Sebagaimana pada Q.S. al-Baqarah ayat 87, yang kira-kira asalnya adalah

Menjadi

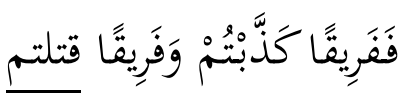

$$
\text { فَغَرِيقًا كَذََُّّْْمْ وَفَرِيقًا تَقْتُلُونَ }
$$

Pada ayat di atas, para uama menyatakan, bahwa mestinya kata yang digunakan dalam bentuk mâdhi, yaitu kata qataltum, karena memang kata sebelumnya juga berbentuk mâdhi, yaitu kadzabtum. Tetapi nyatanya yang digunakan adalah bentuk mudhâri'nya yaitu kata taqtulûn. Ini tidak lain karena menyesuaikan dengan akhir bunyi ayat sebelumnya dan akhir bunyi ayat sesudahnya.

Demikian beberapa contoh tentang betapa luar biasaan keserasian dan keharmonisan bunyi ayat-ayat al-Qur'an. Sebenarnya masih banyak lagi contoh bisa disebutkan, tetapi tentu saja tidak akan cukup di artikel yang terbatas ini. 


\section{Penutup}

Demikianlah isi pembahasan makalah ini. Seputar kisikisi keindahan bahasa al-Qur'an, dari sisi keunikan kata, keindahan susunan kalimat, juga dari sisi gambaran atau visaulisasi yang kuat dan mengena, juga tentang rahasia keserasian bunyi dan nada dalam al-Qur'an. Melalui kajian dan pembahasan di atas, pembaca diajak memahami betapa indahnya dan luar biasanya bahasa al-Qur'an yang menyentuh akal dan jiwa sekaligus. Pembaca juga diajak memahami, mengagumi, menikmati keindahan dan keunikan bahasa al-Qur'an tersebut.

Sebagai penelitian pendahuluan mengenai tema ini, tentu saja ini banyak kekurangan di sana-sini. Sebaiknya penelitian ini, diikuti oleh penelitian lanjuan, yang lebih mengeksplorasi berbagai sisi bahasa al-Qur'an. 


\section{Daftar Pustaka}

Al-Jurjânî, ‘Abd al-Qâhir, Dalâil al-I'jâz, Damaskus: tp, 1987.

Al-Zarqâni, Manahil al-'Irfân fi 'Ulûm al-Qur'ân, Beirut: Dâr Ihya' al-Kutub al-'Ilmiyah, 2004).

Al-Bâqilânî, I'jâz al-Qur'ân, Kairo: Dâr al-Ma'ârif, 1963.

Ar-Rûmâni, al-Nukat fì I'jâz al-Qur'ân, Kairo: Dâr al-Ma'ârif, 1976.

Al-Qathalâni, Lathâ'if al-Isyârah li Funûn al-Qira'ât, (Madinah: Wuzârah al-Syu'ûn al-Islâmiyah wa al-Auqâf, wa alDa'wah wa al-Irsyâd, th.

Amîn, Bakrî Syaikh, al-Ta'bîr al-Fannî fi al-Qur'ân, cet. IV, Kairo: Dâr al-Syurûq, 1980.

Al-Balkhî, Muqâtil bin Sulaiman al-Balkhî, al-Mujûh wa alNazhâir fi al-Qur'ân al- 'Azhîm, Dubai: Markaz Jam'ah al-Mâjid li al-Tsaqâfah wa al-Turâts, 2006.

Al-Dâmighânî, al-Imâm al-Syaikh Abî 'Abdillah alMuhammad, al-Wujûh wa al-Nazhâir li Alfâzh Kitâbillah al- 'Aziz, Beirut: Dâr al-Kutub al-'Ilmiah, th.

Al-Munjid, Mahmûd Nûr al-Dîn, al-Isytirâk al-Lafzhy fi alQur'ân al-Karîm, Beirut: Dâr al-Fikr al-Mu'âshir, 1999.

Ar-Râfi' î, I'jâz al-Qur'ân wa al-Balâghah al-Qur'âniyah, Beirut: Dâr al-'Arabiyah, 1973.

As-Sabt, Khâlid Utsman, diterj. Salman Harun, Kaidah-Kaidah Tafsir, Jakarta: PT. Qaf Media Kreativa, 2017.

As-Suyûthi, al-Itqân fi Ulûm al-Qur'ân, jilid 2, cet. III, TK: alHalabi, 1951.

Fitriyah, Tika, "Stilistika Kisah Nabi Luth dalam al-Qur'an", Tesis Program Pascasarjana UIN Sunan Kalijaga Yogyakarta, Prodi Studi Agama Islam dan Filsafat, konsentrasi ilmu bahasa Arab, 2015.

Hamdani, Wagiono Hamid dan Abdurrahman, Maman, "Fenomena Polisemik Bahasa Arab dalam al-Qur'an dan Implikasi Pembelajarannya", dalam jurnal Bahasa dan Sastra, UPI, Vol. 14, No. 1, April 2014.

Husein 'Abd al-Qâdir, al-Qur'ân: I'jâzuhu wa Balâghatuhu, Kairo: al-Amânah, 1975.

Iwatunnisa, Khalida, "Keserasian Bunyi Akhir Ayat dalam QS. al-Insyirah: Kajian Aspek Fonologi al-Qur'an”, Skripsi Jurusan Ilmu al-Qur'an dan Tafsir, Fakultas Ushuluddin dan Pemikiran Islam, UIN Sunan Kalijaga Yogyakarta, 2015. 
Istianah, "Stilistika al-Qur'an: Pendekatan Sastra Sebagai Analisis dalam Menginterpretasikan al-Qur'an", dalam jurnal Hermeneutika, diterbitkan STAIN Kudus, Vol. 8, No, 2, Desember 2014.

Muhammad, Ahsin Sakho, Oase al-Qur'an: Penyejuk Kehidupan, Jakarta: Penerbit Qaf, 2017.

Mahsun, Metode Penelitian Bahasa, Jakarta: Rajawali Press, 2005.

Maimun, Muhammad, "Kosa Kata Asing dalam al-Qur'an”, Tesis Program Pascasarjana UIN Sunan Kalijaga Yogyakartam 2010.

Mukhlas, Moh., "Fenomena Pragmatis dalam al-Qur'an: Kajian Atas Bentuk Imperatif pada Surah an-Nur", dalam jurnal At-Ta'dib, Universitas Darussalam Gontor, Vol. 9, No. 1, Juni 2014.

Muhammad al-[̈asnâwî, al-Fâshilah fi al-Qur'ân, Beirut: tp, 1986.

Nurhidayat, "Penggunaan Gaya Bahasa Simile dalam al-Qur'an", dalam jurnal Manhaj, diterbitkan Fakultas Tarbiyah dan Tadris IAIN Bengkulu, Vol. 4 No. 2, Mei-Agustus 2016.

Narbuko, Cholid dan Achmadi, Abu, Metodologi Penelitian, cet.II, Jakarta: Bumi Aksara, 2001.

Qalyubi, Syuhbanuddin, "Stilistika Kisah Ibrahim dalam alQur'an", Disertasi UIN Sunan Kalijaga Yogyakarta, 2006.

Raudhatussolihah, Baiq, "Analisis Linguistikk dalam al-Qur'an: Studi Semantik Terhadap QS. al-“Alaq”, Tesis pada Program Pascasarjana UIN Alauddin Makassar, 2016.

Ratna, Nyoman Kutha, Metode Penelitian: Kajian Budaya dan Sosio Humaniora Pada Umumnya, Yogyakarta: Pustaka Pelajar, 2010.

Shihab, M. Quraish, Membumikan al-Qur'an, Bandung: Penerbit Mizan, 1992.

Tafsir Al-Misbah: Pesan, Kesan, dan Keserasian AlQur'an, Jakarta: Lentera hati, 2002.

Sayuti Anshari, Ahmad, Fonetik dan Fonologi al-Qur'an, Jakarta: Penerbit Amzah, 2012.

, "Sifat-Sifat Bunyi al-Qur'an: Sebuah Tinjauan Fonetis", dimuat di Misykat, jurnal Pascasarjana IIQ Jakarta, Vol. III, No. 1 Februari, 2010. 
Sunny, Suniarti, "Gaya Bahasa dalam Surah Ar-Rahman: Kajian Stilistika", Tesis Program Pascasarjana UIN Sunan Kalijaga Yogyakarta, 2014.

Suryabrata, Sumadi, Metodologi Penelitian, cet. II, Jakarta: Rajawali Press, 1985.

Tricahyo, Agus, "Stilistika al-Qur'an: Memahami Fenomena Kebahasaan al-Qur'an dalam Penciptaan Manusia", dalam jurnal Dialogia, diterbitkan oleh STAIN Ponorogo, Vol. 12, No. 1, Juni 2014.

'Umâr, Ahmad Mukhtâr, Lughat al-Qur'an, Dirâsah Tautsiqiyah Fanniyah, Kuwait: Muassasah al-Kuwait Li Taqaddum al-'Ilmî, 1997.

Qal'ahji, Muhammad Rawwas, Lughat al-Qur'ân Lughat al'Arab al-Mukhtârah, Dharhan, Dâr al-Nafâ'is, 2017.

Quthb, Sayyid, Masyâhid al-Qiyâmah fi al-Qur'ân, cet. XVI (Kairo, Dâr al-Syurûq, 2006). 